\title{
Relating vesicle shapes in pyroclasts to eruption styles
}

\author{
Pranabendu Moitra • Helge M. Gonnermann • \\ Bruce F. Houghton · Thomas Giachetti
}

Received: 11 June 2012 / Accepted: 16 January 2013

(C) Springer-Verlag Berlin Heidelberg 2013

\begin{abstract}
Vesicles in pyroclasts provide a direct record of conduit conditions during explosive volcanic eruptions. Although their numbers and sizes are used routinely to infer aspects of eruption dynamics, vesicle shape remains an underutilized parameter. We have quantified vesicle shapes in pyroclasts from fall deposits of seven explosive eruptions of different styles, using the dimensionless shape factor $\Omega$, a measure of the degree of complexity of the bounding surface of an object. For each of the seven eruptions, we have also estimated the capillary number, $\mathrm{Ca}$, from the magma expansion velocity through coupled diffusive bubble growth and conduit flow modeling. We find that $\Omega$ is smaller for eruptions with $\mathrm{Ca} \ll 1$ than for eruptions with $\mathrm{Ca} \gg 1$. Consistent with previous studies, we interpret these results as an expression of the relative importance of structural changes during magma decompression and bubble growth, such as coalescence and shape relaxation of bubbles by capillary stresses. Among the samples analyzed, Strombolian and Hawaiian fire-fountain eruptions have $\mathrm{Ca} \ll 1$, in contrast to Vulcanian, Plinian, and ultraplinian eruptions. Interestingly, the basaltic Plinian eruptions of Tarawera volcano, New Zealand in 1886 and Mt. Etna, Italy in 122 $\mathrm{BC}$, for which the cause of intense explosive activity has
\end{abstract}

Editorial responsibility: J.E. Gardner

P. Moitra $(\varangle)$ · H. M. Gonnermann · T. Giachetti Department of Earth Science, Rice University, 6100 Main Street, MS 126, Houston, TX 77005, USA

e-mail: pm10@rice.edu

B. F. Houghton

Department of Geology and Geophysics, University of Hawai ' $\mathrm{i}$ at Manoa, 1680 East-West Road, Honolulu, HI 96822, USA been controversial, are also characterized by $\mathrm{Ca} \gg 1$ and larger values of $\Omega$ than Strombolian and Hawaiian style (fire fountain) eruptions. We interpret this to be the consequence of syn-eruptive magma crystallization, resulting in high magma viscosity and reduced rates of bubble growth. Our model results indicate that during these basaltic Plinian eruptions, buildup of bubble overpressure resulted in brittle magma fragmentation.

Keywords Vesicle shape $\cdot$ Pyroclast $\cdot$ Basaltic Plinian eruption · Regularity · Capillary number · Bubble growth · Conduit flow model $\cdot$ Magma fragmentation

\section{Introduction}

Direct observation of the processes governing explosive volcanic eruptions is difficult, if not impossible. Pyroclasts represent quenched fragments of magma and often preserve abundant bubbles (in melt) in the form of vesicles (in rock). These vesicles provide an indirect record of magma ascent conditions. A significant body of work has been aimed at using bubble number density and size distributions to constrain rates of eruptive magma ascent and the timing of gas exsolution (e.g., Mangan et al. 1993; Cashman and Mangan 1994; Polacci et al. 2003; Burgisser and Gardner 2005; Proussevitch et al. 2007). Vesicle shape is another manifestation of magma ascent conditions, in particular bubble growth, coalescence, and shearing (e.g., Klug and Cashman 1996; Mangan and Cashmann 1996; Polacci et al. 2003; Rust et al. 2003; Okumura et al. 2008; Wright and Weinberg 2009), and can therefore provide a valuable complement to conventional studies of pyroclast textures. 
Table 1 Symbols used in this paper and their units with description

\begin{tabular}{|c|c|c|}
\hline Symbol & Unit & Description \\
\hline$a$ & $\mathrm{~m}$ & Conduit radius \\
\hline$A$ & $\mathrm{~m}^{2}$ & Area of vesicle \\
\hline$c$ & $\mathrm{wt} \%$ & Concentration of dissolved volatiles inside the melt \\
\hline$c_{R}$ & $\mathrm{wt} \%$ & Concentration of volatiles at the vapor-melt interface \\
\hline $\mathrm{Ca}$ & & Capillary number \\
\hline$d P_{\mathrm{m}} / d t$ & $\mathrm{MPa} \mathrm{s}^{-1}$ & Magma decompression rate \\
\hline$D$ & $\mathrm{~m}^{2} \mathrm{~s}^{-1}$ & Diffusivity of $\mathrm{H}_{2} \mathrm{O}$ \\
\hline$f_{\mathrm{m}}$ & & Friction factor \\
\hline$f_{0}$ & & Constant to calculate friction factor \\
\hline$g$ & $\mathrm{~m} \mathrm{~s}^{-2}$ & Gravitational acceleration \\
\hline$G$ & $\mathrm{~ms}^{-1}$ & Crystal growth rate \\
\hline$H$ & $\mathrm{~km}$ & Plume height \\
\hline$I$ & $\mathrm{~m}^{-3} \mathrm{~s}^{-1}$ & Crystal nucleation rate \\
\hline$k_{\mathrm{V}}$ & & Volumetric shape factor \\
\hline$N_{\mathrm{m}}$ & $\mathrm{m}^{-3}$ & Bubble number density per unit volume of melt \\
\hline$P_{\text {initial }}$ & $\mathrm{Pa}$ & Initial saturation pressure \\
\hline$P_{\text {frag }}$ & $\mathrm{Pa}$ & Ambient melt pressure outside bubble at fragmentation \\
\hline$P_{\mathrm{g}}$ & $\mathrm{Pa}$ & Gas pressure inside the bubble \\
\hline$P_{\mathrm{m}}$ & $\mathrm{Pa}$ & Ambient melt pressure outside the bubble \\
\hline$P_{\text {vent }}$ & $\mathrm{Pa}$ & Pressure at vent \\
\hline$Q$ & $\mathrm{~kg} \mathrm{~s}^{-1}$ & Magma discharge rate \\
\hline$r$ & $\mathrm{~m}$ & Radial coordinate \\
\hline$R$ & $\mathrm{~m}$ & Bubble radius \\
\hline $\operatorname{Re}$ & & Reynolds number \\
\hline$S$ & $\mathrm{~m}$ & Half distance between two adjacent bubbles \\
\hline$t$ & s & Time \\
\hline$u$ & $\mathrm{~m} \mathrm{~s}^{-1}$ & Magma ascent velocity \\
\hline$u_{\mathrm{str}}$ & $\mathrm{m} \mathrm{s}^{-1}$ & Ascent velocity of gas slug \\
\hline$v_{\mathrm{e}}$ & $\mathrm{m} \mathrm{s}^{-1}$ & Expansion velocity \\
\hline$v_{r}$ & $\mathrm{~m} \mathrm{~s}^{-1}$ & Radial velocity at radius $r$ \\
\hline$v_{R}$ & $\mathrm{~ms}^{-1}$ & Bubble growth rate \\
\hline$V$ & $\mathrm{~m}^{3}$ & Total volume of magma erupted \\
\hline$z$ & $\mathrm{~m}$ & Depth of conduit \\
\hline$z_{\text {initial }}$ & $\mathrm{m}$ & Initial depth of conduit \\
\hline$\Delta P$ & $\mathrm{~Pa}$ & Bubble overpressure \\
\hline$\Delta P_{\mathrm{f}}$ & $\mathrm{Pa}$ & Fragmentation threshold \\
\hline$\eta$ & $\operatorname{Pas}$ & Viscosity of melt \\
\hline$\eta_{\mathrm{e}}$ & Pas & Effective viscosity \\
\hline$\kappa$ & $\mathrm{m}^{2}$ & Magma permeability \\
\hline$\lambda_{1}$ & $\mathrm{~m}$ & Semi-long axis \\
\hline$\lambda_{\mathrm{s}}$ & $\mathrm{m}$ & Semi-short axis \\
\hline$\rho$ & $\mathrm{kg} \mathrm{m}^{-3}$ & Density of magma \\
\hline$\rho_{\mathrm{g}}$ & $\mathrm{kg} \mathrm{m}^{-3}$ & Density of gas phase inside bubble \\
\hline$\rho_{\mathrm{m}}$ & $\mathrm{kg} \mathrm{m}^{-3}$ & Density of melt \\
\hline$\sigma$ & $\mathrm{Nm}^{-1}$ & Surface tension \\
\hline$\tau_{\text {relaxation }}$ & $\mathrm{s}$ & Shape relaxation time scale \\
\hline$\tau_{\text {quenching }}$ & $\mathrm{s}$ & Viscous quench time scale of pyroclast \\
\hline$\phi$ & & Volume fraction of vesicles \\
\hline$\phi_{x}$ & & Volume fraction of crystals in the groundmass \\
\hline$\Omega$ & & Regularity (as defined by Shea et al. 2010) \\
\hline
\end{tabular}


Table 2 Eruption parameters and microtextural characteristics of pyroclasts from the eruptions studied

\begin{tabular}{|c|c|c|c|c|c|c|c|}
\hline $\begin{array}{l}\text { Eruption } \\
\text { Date }\end{array}$ & $\begin{array}{l}\text { Kilauea Iki } \\
(1959)\end{array}$ & $\begin{array}{l}\text { Stromboli } \\
(2002)\end{array}$ & $\begin{array}{l}\text { Soufrière Hills } \\
\text { (1997) }\end{array}$ & $\begin{array}{l}\text { Novarupta } \\
(1912)\end{array}$ & $\begin{array}{l}\text { Taupo } \\
(1.8 \mathrm{ka})\end{array}$ & $\begin{array}{l}\text { Tarawera } \\
(1886)\end{array}$ & $\begin{array}{l}\text { Etna } \\
(122 \mathrm{BC})\end{array}$ \\
\hline Style & Fire fountain & Strombolian & Vulcanian & Plinian & Ultraplinian & Plinian & Plinian \\
\hline Melt & Basalt & Basalt & Rhyolite & Rhyolite & Rhyolite & Basalt & Basalt \\
\hline$a(\mathrm{~m})$ & 7.6 & 4 & 15 & 50 & 50 & 25 & 25 \\
\hline$H(\mathrm{~km})$ & 0.314 & $0.12-0.3$ & $3-15$ & 24 & 55 & 28 & $24-26$ \\
\hline$N_{\mathrm{m}} \times 10^{13}\left(\mathrm{~m}^{-3}\right)$ & $0.54-1.6$ & $0.17-0.34$ & $159-668$ & $2.8-210$ & $1-536$ & $0.15-0.25$ & $0.3-9$ \\
\hline$Q\left(\mathrm{~kg} \mathrm{~s}^{-1}\right)$ & $4.5 \times 10^{5}$ & $2-1,700$ & $1.3 \times 10^{7}$ & $5 \times 10^{7}$ & $10^{8}-10^{10}$ & $1.5 \times 10^{7}$ & $8.5 \times 10^{7}$ \\
\hline $\mathrm{T}\left({ }^{\circ} \mathrm{C}\right)$ & 1,170 & 1,100 & 850 & 850 & $\sim 850$ & 1,100 & 1,100 \\
\hline$V\left(\mathrm{~km}^{3}\right)$ & 0.15 & - & 0.15 & 10 & 35 & 2 & 0.4 \\
\hline VEI & 2 & $\leq 2$ & 3 & 6 & 7 & 5 & 4 \\
\hline$\phi(\%)$ & $54-88$ & $66-76$ & $24-79$ & $52-74$ & $76-93$ & $20-70$ & $30-80$ \\
\hline$\rho_{\mathrm{m}}\left(\mathrm{kg} \mathrm{m}^{-3}\right)$ & 2,800 & 2,750 & 2,600 & 2,400 & 2,400 & 2,700 & 2,700 \\
\hline Reference & $(1,2,3)$ & $(4,5)$ & $(6,7,8)$ & $(9,10)$ & $(11,12,13)$ & (14) & $(15,16,17)$ \\
\hline
\end{tabular}

(1) Parfitt (2004), (2) Stovall et al. (2011), (3) Wallace (1998), (4) Lautze and Houghton (2007), (5) Pistolesi et al. (2011), (6) Burgisser et al. (2010), (7) Giachetti et al. (2010), (8) Druitt et al. (2002), (9) Adams et al. (2006), (10) Hildreth and Fierstein (2012), (11) Houghton et al. (2010), (12) Walker (1980), (13) Dunbar et al. (1989), (14) Sable et al. (2009), (15) Coltelli et al. (1998), (16) Sable et al. (2006), (17) Giordano (2003)

Here, we study vesicle shapes in pyroclasts from fall deposits of seven explosive eruptions, comprising six different eruptive styles, including the enigmatic Plinian eruptions of basaltic magma, for which the cause for high explosive intensity has been controversial (e.g., Walker et al. 1984; Coltelli et al. 1998; Houghton et al. 2004; Sable et al. 2006, 2009; Costantini et al. 2009; Goepfert and Gardner 2010). We are primarily interested in the relationship between bubble growth, as a consequence of magma decompression, and vesicle shape. We therefore restrict our analysis to samples with vesicles that are not significantly affected by shear deformation, that is samples where the median elongation is small $(\leq 0.35$, e.g., Rust and Manga 2002a; Rust et al. 2003). We interpret vesicle shapes within the context of recent work on the relationship between the "structure" of expanding bubbly fluids, that is bubble shapes, and capillary number (Koerner 2008). By estimating the capillary number, $\mathrm{Ca}$, (see also Table 1 for notations) through bubble growth modeling, we relate the overpressure of bubbles, which is proportional to the energy needed to initiate and sustain magma fragmentation (Mueller et al. 2008), to vesicle shapes in the analyzed pyroclasts.

\section{Eruptions studied}

In order to relate vesicle shapes and capillary number, we analyzed pyroclasts from fall deposits of well-constrained eruptions over a wide range of eruption styles and intensities (Table 2), as well as compositions (Table 3). They
Table 3 Oxide concentrations in weight percent. Oxide concentrations of major element compositions are reported on a volatile-free basis

(1) Wallace (1998), (2) Lautze (2005), (3) Burton et al. (2007), (4) Burgisser et al. (2010), (5) Hildreth and Fierstein (2012), (6) Hammer et al. (2002), (7) Dunbar and Kyle (1993), (8) Gamble et al. (1990), (9) Sable et al. (2009), (10) Coltelli et al. (1998), (11) Del Carlo and Pompilio (2004)

\begin{tabular}{lccccrrr}
\hline & Kilauea Iki & Stromboli & Soufrière Hills & Novarupta & Taupo & Tarawera & Etna \\
\hline $\mathrm{SiO}_{2}$ & 49.50 & 52.75 & 78.66 & 79.09 & 74.20 & 50.93 & 49.09 \\
$\mathrm{TiO}_{2}$ & 2.41 & 1.69 & 0.39 & 0.24 & 0.30 & 0.83 & 1.58 \\
$\mathrm{Al}_{2} \mathrm{O}_{3}$ & 12.20 & 15.71 & 11.20 & 11.70 & 13.70 & 17.27 & 18.54 \\
$\mathrm{FeO}$ & 12.20 & 10.13 & 1.93 & 0.71 & 2.60 & 10.48 & 10.32 \\
$\mathrm{MnO}$ & 0.17 & 0.17 & 0.10 & 0.01 & 0.10 & 0.17 & 0.19 \\
$\mathrm{MgO}$ & 9.35 & 3.47 & 0.30 & 0.10 & 0.30 & 6.21 & 4.76 \\
$\mathrm{CaO}$ & 11.50 & 7.47 & 1.48 & 0.81 & 1.60 & 11.41 & 9.48 \\
$\mathrm{Na} 2 \mathrm{O}$ & 2.07 & 3.40 & 3.57 & 4.12 & 4.40 & 2.13 & 3.99 \\
$\mathrm{~K}_{2} \mathrm{O}$ & 0.43 & 4.21 & 2.38 & 3.22 & 2.70 & 0.55 & 1.53 \\
$\mathrm{P}_{2} \mathrm{O}_{5}$ & 0.26 & 1.01 & 0.00 & 0.00 & 0.00 & 0.01 & 0.51 \\
$\mathrm{H}_{2} \mathrm{O}$ & 0.70 & 3.00 & 3.40 & 2.80 & 4.00 & 3.00 & 2.00 \\
$\mathrm{Reference}$ & $(1)$ & $(2,3)$ & $(4)$ & $(5,6)$ & $(7)$ & $(8,9)$ & $(10,11)$ \\
\hline
\end{tabular}


Table 4 Summary of vesicle shape analysis

\begin{tabular}{llllcc}
\hline Eruption & Sample & Reference & $\phi(\%)$ & No. ves. analyzed & Median $\Omega$ \\
\hline Kilauea Iki & 6A1 & Houghton unpublished data & 75 & 1,245 & 0.994 \\
Stromboli & $19-11$ & Lautze and Houghton (2007) & 73 & 94 & 0.994 \\
Soufrière Hills & R2 & Giachetti et al. (2010) & 56 & 1,223 & 0.944 \\
Novarupta & $94-1-8-9$ & Adams et al. (2006) & 75 & 3,197 & 0.933 \\
Taupo & MF01102 & Houghton et al. (2010) & 79 & 496 & 0.926 \\
Mt. Tarawera & T43-07-67 & Sable et al. (2009) & 59 & 170 & 0.960 \\
Mt. Etna & $07 \_23$ & Sable et al. (2006) & 67 & 1,564 & 0.929 \\
\hline
\end{tabular}

are (1) the basaltic 1959 high-fountaining eruption at Kilauea Iki, Hawai'i (Stovall et al. 2011), (2) a basaltic Strombolian eruption at Stromboli, Italy in 2002 (Lautze and Houghton 2007), (3) a typical Vulcanian eruption at Soufrière Hills, Montserrat in 1997 (Druitt et al. 2002), (4) the dacitic-rhyolitic 1912 Plinian eruption of Novarupta, Alaska (Adams et al. 2006), (5) the $1.8 \mathrm{ka}$ ultraplinian eruption in Taupo, New Zealand (Houghton et al. 2010), and two basaltic Plinian eruptions (6) Mt. Etna, Italy in 122 BC (Sable et al. 2006) and (7) Mt. Tarawera, New Zealand in 1886 (Sable et al. 2009). For each eruption, we analyze vesicle shapes of a modal sample (Table 4) that is representative of the given deposit in terms of composition, vesicle size distribution, vesicle number density, and qualitative appearance of vesicle shapes.

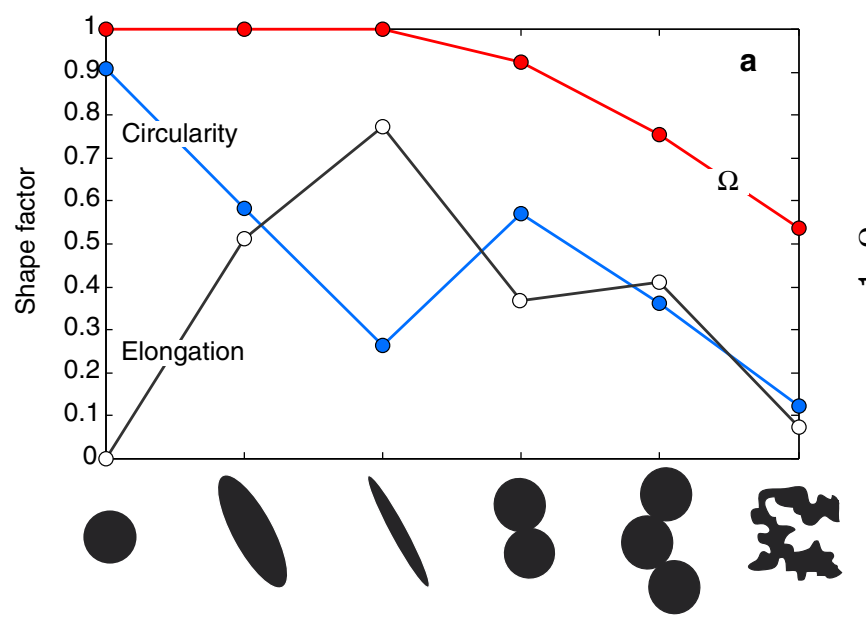

Fig. 1 a Comparison of different shape factors - circularity, elongation, and $\Omega$ (see text for formulations) for six hypothetical vesicle shapes. From left to right, the vesicles represent a spherical vesicle, an elongated (sheared) vesicle with an aspect ratio of approximately $3: 1$, an elongated (sheared) vesicle with an aspect ratio of approximately $8: 1$, a vesicle formed by the coalescence of two bubbles, a vesicle formed by the coalescence of three bubbles, and a complexly shaped vesicle formed due to the coalescence of many bubbles. Among the

\section{Quantifying vesicle shapes}

\section{Shape parameter, $\Omega$}

Our focus in this study is to quantify the shapes of vesicles, with an emphasis on distinguishing shapes produced by the coalescence of two or more vesicles. To identify a suitable metric, we compared the values of shape parameters for various hypothetical vesicle shapes. As illustrated in Fig. 1a, elongation, defined as $\left(\lambda_{1}-\lambda_{s}\right) /\left(\lambda_{1}+\lambda_{s}\right)$ (e.g., Rust and Manga 2002a; Rust et al. 2003), and circularity, the ratio of cross-sectional area and surface area (e.g., Russ and Dehoff 2000), are significantly affected by bubbles that are elongated due to shear deformation. Here, $\lambda_{1}$ and $\lambda_{\mathrm{s}}$ are

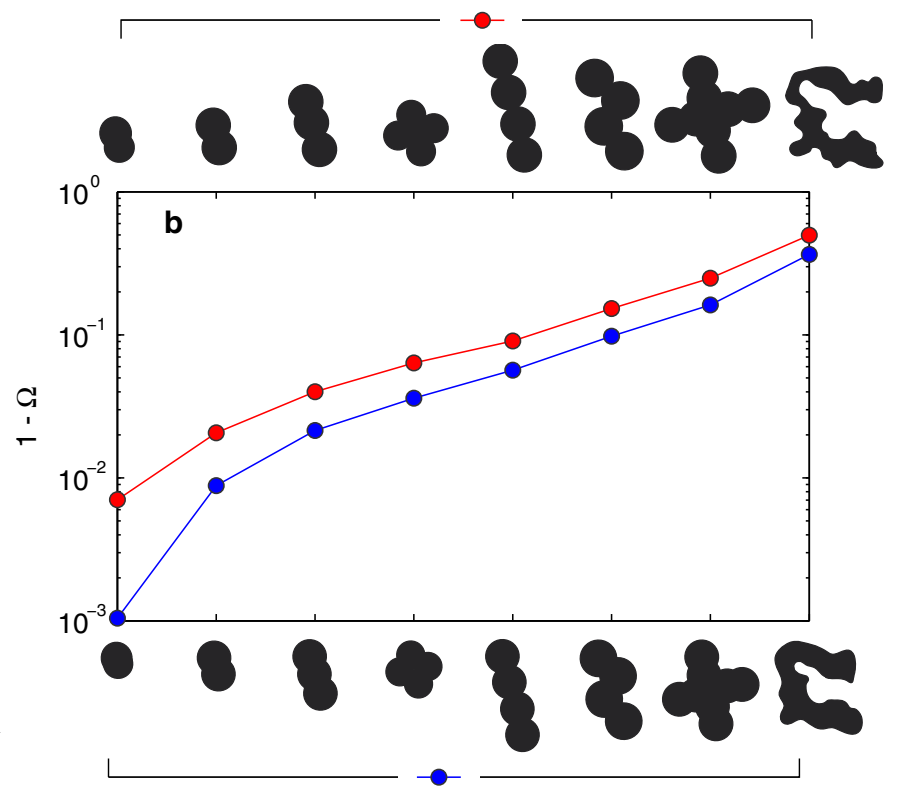

different shape factors, $\Omega$ is not affected by vesicle elongation and represents a robust metric for vesicles with complexly shaped margins, that is convolutely shaped vesicles. b Illustrating $(1-\Omega)$ for hypothetical vesicle shapes. Blue curve is for vesicles that are identical to the red ones, with somewhat more gradual changes in curvature of the vesicle perimeter. As illustrated, the measure, $(1-\Omega)$, increases with increasing complexity of vesicle shapes 
the semi-long and semi-short axes of the best-fit ellipse, respectively. In contrast, the shape parameter,

$\Omega=\frac{A}{\pi \lambda_{1} \lambda_{\mathrm{s}}}$,

defined as "regularity" by Shea et al. (2010), is not affected by vesicle elongation but is sensitive to vesicles with complex margins. Figure 1a illustrates that only vesicles with complex margins have values of $\Omega<1$. We therefore use $\Omega$ as a metric to differentiate vesicles that preserve shapes due to unrelaxed coalescence events from more spheroidal vesicles. Because $\Omega$ is a rather sensitive measure of vesicle shape, small deviation from $\Omega=1$ can represent significant complexity in vesicle shapes. It is therefore convenient to show $(1-\Omega)$ together with $\Omega$ (Fig. 1b).

For each of the considered eruptions, $\Omega$ was calculated for vesicles with cross-sectional areas that are equivalent to circular areas with diameters ranging from 10 to $100 \mu \mathrm{m}$. This size range includes median vesicle size range observed in pyroclasts for all of the eruptions studied. Vesicle shapes are analyzed using a fixed magnification to ensure the same pixel resolution throughout. Thus, vesicle shapes were analyzed on all the vesicles imaged at a scale of $1 \mu \mathrm{m} / \mathrm{px}(\times 100$ magnification) in backscattered electron images from a given thin section, previously used for the study of vesicle size distributions (Tables 2 and 4; Adams et al. 2006; Sable et al. 2006, 2009; Lautze and Houghton 2007; Giachetti et al. 2010; Houghton et al. 2010; Stovall et al. 2011). In these studies, the original, grayscale, SEM images were transformed into binary images using Adobe ${ }^{\circledR}$ Photoshop and Scion Image (Scion Corporation, USA) or ImageJ (Schneider et al. 2012) software. In these binary images, vesicles are black and solid phases are white. Manual editing of the images was required to rebuild vesicle walls that were thought to have broken during thin sample preparation and

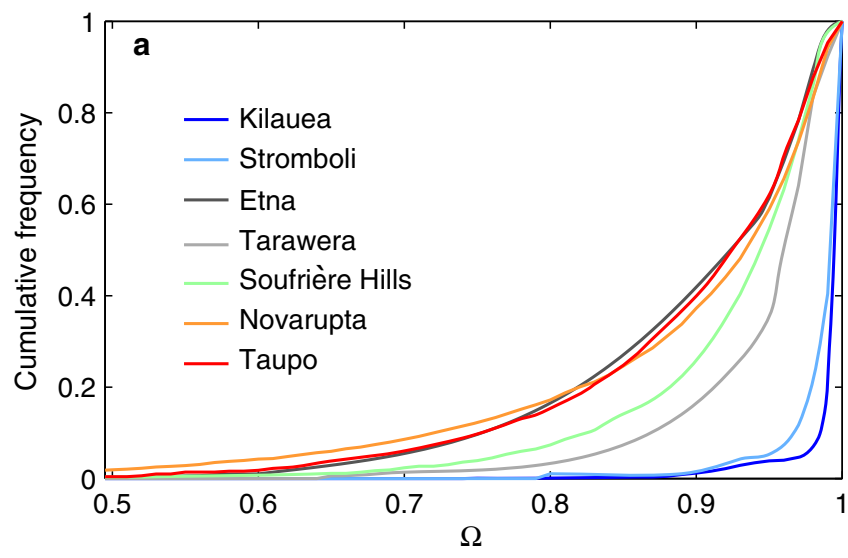

Fig. 2 Cumulative frequency distributions of $\mathbf{a} \Omega$ and $\mathbf{b}(1-\Omega)$ for the seven eruptions studied. $\Omega$ is calculated for vesicles with an equivalent diameter between 10 and $100 \mu \mathrm{m}$ for the samples listed in Table 4 . The values of $\Omega$ are shown for $\Omega \geq 0.5$ as the frequency of occurrence of to remove flaws, such as grinding compound. In addition, thin bubble walls were often lost during image acquisition or during the conversion from grayscale to binary and also had to be redrawn. The original images had been positioned to avoid areas with large crystals. In this study, we analyzed these binary images. The reader is referred to the corresponding papers for more details concerning the acquisition and processing of the SEM images used herein.

\section{Measured vesicle shapes}

The cumulative frequency distribution of $\Omega$ and $(1-\Omega)$ for the seven eruptions studied is shown in Fig. 2a, b, respectively. Although the minimum value of $\Omega$ measured for all the eruptions is 0.27 , we show from $\Omega=0.5$ as values smaller than this have a very low frequency of occurrence. Figure 2a shows that vesicles in pyroclasts from Strombolian and Hawaiian fire-fountain eruptions have distinctly higher values of $\Omega$ than vesicles in pyroclasts from the other eruptions. This distinction is more pronounced in Fig. 2b. Under "Results and discussion" we will provide an interpretation of these results.

\section{Capillary number, $\mathbf{C a}$}

The capillary number represents the balance of viscous and capillary stresses. The latter tends to restore deformed bubbles toward spherical shape, whereas the former is the consequence of fluid motions that deform bubbles (Stone 1994). The capillary number can be expressed as the product of dynamic viscosity and flow velocity, divided by surface tension. This requires a judicious choice of flow velocity and is typically associated with an externally imposed shear

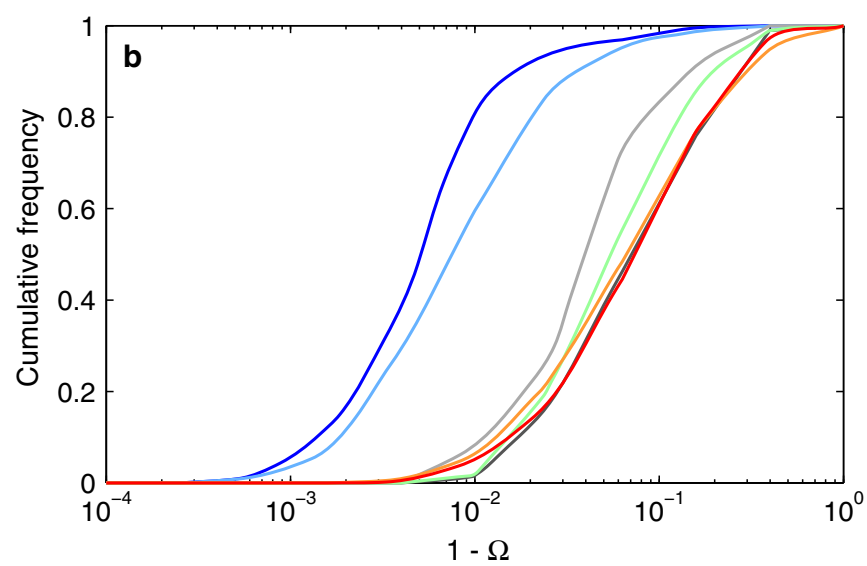

smaller values of $\Omega$ is close to 0 . Measured minimum value of $\Omega$ is 0.27 for all the eruptions. Vesicles in Hawaiian and Strombolian pyroclasts have distinctly higher values of $\Omega$ than all other eruptions. This distinction is more pronounced in $\mathbf{b}$ 
flow (Taylor 1932, 1934; Rallison 1984; Stone 1994; Rust and Manga 2002a, b; Rust et al. 2003). An alternate possibility is the "expansion velocity," $v_{\mathrm{e}}$, of a bubbly fluid (Koerner 2008), defined as the velocity at which the surface of a bubbly fluid or foam is expanding upon bubble growth (Namiki and Manga 2006; Koerner 2008). For an unconfined fluid with bubbles of average size $R$, at a volume fraction $\phi$, the expansion velocity is

$v_{\mathrm{e}}=\phi^{2 / 3} \frac{d R}{d t}=\phi^{2 / 3} v_{R}$

where $t$ denotes time. The balance between viscous and capillary stresses, expressed in terms of $v_{\mathrm{e}}$, thus gives

$\mathrm{Ca}=\frac{\eta v_{\mathrm{e}}}{\sigma}$

where $\eta$ is the viscosity of the fluid phase and $\sigma$ is surface tension.

Koerner (2008) provides an analysis of the evolving structure of expanding bubbly fluids in relation to capillary number. Material rearrangement, which is necessary during expansion of a highly vesicular bubbly fluid, results in bubble coalescence. At the same time, capillary stresses cause coalesced bubbles to relax toward a "regular" shape (e.g.,

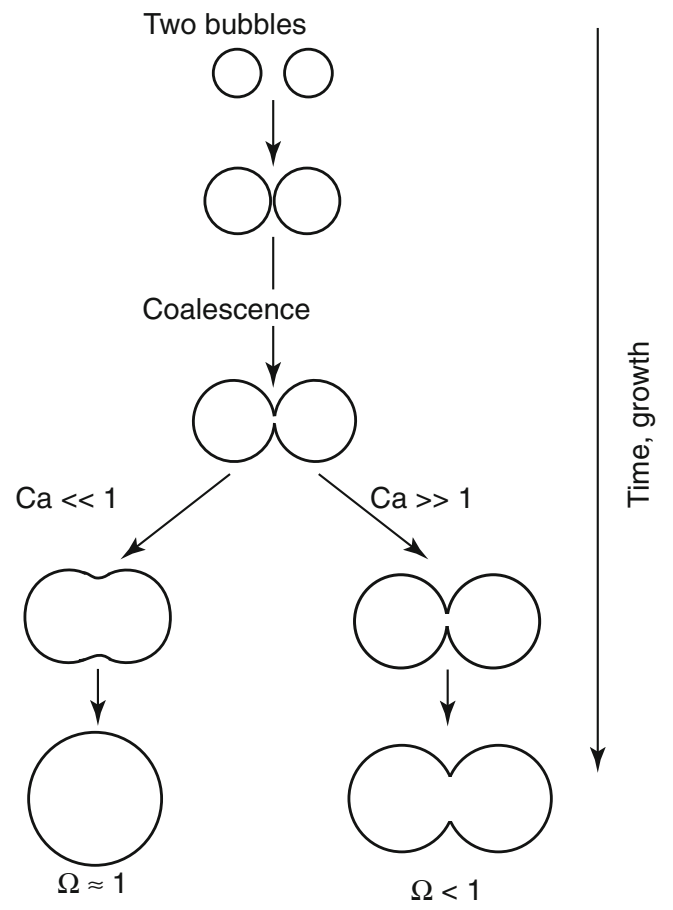

Fig. 3 Schematic diagram illustrating the dependence of $\Omega$ on capillary number, $\mathrm{Ca}$. During magma ascent, bubbles grow and coalesce with each other. Coalesced bubbles relax due to capillary forces while bubble growth continues. If bubble shape relaxation rate exceeds bubble growth rate $(\mathrm{Ca} \ll 1)$, coalesced bubbles relax back to spherical shape $(\Omega \approx 1)$. On the other hand, for $\mathrm{Ca} \gg 1$, bubble shape relaxation becomes slower and remnants of coalescence events become more persistent, leading to a more complex geometry $(\Omega<1)$
Gardner 2007). For $\mathrm{Ca} \ll 1$, the capillary velocity exceeds the expansion velocity $\left(\sigma / \eta \gg v_{\mathrm{e}}\right)$ and bubble shapes minimize changes in curvature of the interface between bubble and surrounding liquid (Fig. 3). For $\mathrm{Ca} \gg 1$, the speed at which bubbles relax toward a regular shape is reduced and remnants of coalescence events become more persistent (Koerner 2008). By estimating capillary number from modeling of magma expansion for the different eruptions, and by comparing it to vesicle shapes in pyroclasts from these eruptions with vesicularity $\phi>\approx 0.6$, we show that vesicle shapes in pyroclasts bear a relationship to $\mathrm{Ca}$. Because of the dependence of capillary number on the average rate of bubble growth, $v_{R}$, vesicle shapes may provide a quantitative record of magma ascent conditions for some time $\tau$ prior to magma quenching, approximately equal to the viscous time scale, $\eta / \Delta P$, where $\Delta P=P_{\mathrm{g}}-P_{\mathrm{m}}$ is the pressure difference between gas pressure inside the bubble, $P_{\mathrm{g}}$, and the ambient pressure, $P_{\mathrm{m}}$.

\section{Bubble overpressure}

During magma ascent, the decline of confining pressure permits dissolved volatiles to form bubbles of supercritical fluid, due to a decrease in pressure-dependent volatile solubility. If bubble growth is limited by viscosity, $P_{\mathrm{m}}$ may decrease at a faster rate than $P_{\mathrm{g}}$. Consequently, bubbles can become pressurized with respect to the surrounding melt (e.g., Sparks 1978; Gonnermann and Manga 2007). Rapid expansion and/or fragmentation of these pressurized bubbles drives Hawaiian, Vulcanian, sub-Plinian, Plinian, and ultraplinian explosions (e.g., McBirney 1970; Alidibirov 1994; Dingwell 1996; Zhang 1999; Spieler et al. 2004; Koyaguchi 2005). In contrast, during Strombolian explosions much larger bubbles rise independently through relatively low viscosity magma (Vergniolle and Mangan 2000; Parfitt 2004), carrying upward with them magma with smaller bubbles. The large bubbles, also referred to as gas slugs, may be pressurized as they reach the surface (e.g., Ripepe 2001; Pistolesi et al. 2011) and their rupture is thought to constitute Strombolian explosions (Walker 1973; Blackburn et al. 1976; Vergniolle and Mangan 2000).

A relationship between vesicle shape and bubble overpressure, $\Delta P$, may exist through the relationship of capillary number and bubble shape and the dependence of capillary number on $v_{R}$. This dependence may be determined from the momentum balance for an idealized spherical bubble (e.g., Scriven 1959; Arefmanesh and Advani 1991; Proussevitch et al. 1993)

$\Delta P=P_{g}-P_{m}=\frac{2 \sigma}{R}+\frac{4 \eta_{\mathrm{e}}}{R} v_{R}$, 
where $\eta_{\mathrm{e}}$ is the effective viscosity, accounting for the radially variable $\mathrm{H}_{2} \mathrm{O}$-dependent viscosity (Lensky et al. 2001). Expressing Eq. 4 in terms of capillary number gives

$\Delta P=\frac{2 \sigma}{R}\left(1+2 \phi^{-2 / 3} \mathrm{Ca}\right)$.

Because $\Delta P$ is proportional to the potential energy capable of initiating and sustaining magma fragmentation (Mueller et al. 2008), we hypothesize that vesicle shapes in pyroclasts produced during magma fragmentation in explosive volcanic eruptions may provide an indirect manifestation of eruption intensity through the relationship between vesicle shape, capillary number, and $\Delta P$.

\section{Bubble growth modeling}

To estimate capillary numbers, we calculate the expansion velocity, $\phi^{2 / 3} v_{R}$, using a model for diffusive bubble growth. We assume that the pyroclasts represent parcels of magma that were carried to the surface from an initial depth equal to the $\mathrm{H}_{2} \mathrm{O}$ saturation depth for the given eruption. We model a single representative bubble of initial radius of $R=10^{-6} \mathrm{~m}$ and final radius $R \approx 25 \mu \mathrm{m}$, consistent within the 10 to $100 \mu \mathrm{m}$ range in vesicle diameters considered for vesicle shape analysis. Although somewhat larger than the size of a critical bubble nucleus, this choice of initial bubble radius does not significantly affect the model results.

The bubble growth model is based on established formulations (e.g., Amon and Denson 1984; Arefmanesh and Advani 1991; Proussevitch et al. 1993) and $\mathrm{H}_{2} \mathrm{O}$ is the sole volatile phase considered, with a solubility based on Dixon (1997) and Liu et al. (2005) for basaltic and silicic eruptions, respectively. The model couples Eq. 4 with an equation for mass balance,

$\frac{d}{d t}\left(\rho_{\mathrm{g}} R^{3}\right)=3 r^{2} \rho_{\mathrm{m}} D\left(\frac{\delta c}{\delta r}\right)_{r=R}$,

and an equation for the diffusion of $\mathrm{H}_{2} \mathrm{O}$,

$\frac{\delta c}{\delta t}+v_{r} \frac{\delta c}{\delta r}=\frac{1}{r^{2}} \frac{\delta c}{\delta r}\left(D r^{2} \frac{\delta c}{\delta r}\right)$.

Here, $r$ is the radial coordinate, $v_{r}$ is the radial velocity at radius $r$, and $\rho_{\mathrm{g}}$ is the density of the exsolved $\mathrm{H}_{2} \mathrm{O}$, which depends on $P_{\mathrm{g}}$ and is calculated using a modified RedlichKwong equation of state (Kerrick and Jacobs 1981). $c$ is the mass fraction of dissolved $\mathrm{H}_{2} \mathrm{O}$ and $D$ is its diffusivity, which depends on $c$ and temperature. $D$ is based on Eq. 18 of Zhang et al. (2007) for the basaltic eruptions and on Zhang and Behrens (2000) for the silicic eruptions. $c_{R}$ is the $\mathrm{H}_{2} \mathrm{O}$ concentration at the melt-vapor interface and depends on the solubility at $P_{\mathrm{g}}$. The effective viscosity, $\eta_{\mathrm{e}}$, is based on the formulation of Lensky et al. (2001), using the melt viscosity, $\eta$, which depends on melt composition, temperature, and dissolved $\mathrm{H}_{2} \mathrm{O}$ (Hui and Zhang 2007). For basaltic Plinian eruptions, $\eta_{\mathrm{e}}$ includes the effect of microlites on viscosity. For simplicity, we assume a constant value of $\sigma=0.05 \mathrm{~N} \mathrm{~m}^{-1}$. The variability in $\sigma$ is probably less than a factor of 2 (e.g., Gardner and Ketcham 2011 and references therein) and does not affect model results significantly (Gonnermann and Houghton 2012).

The bubble growth calculation is coupled to a model for magma ascent within the conduit, from which we obtain the decompression rate, $d P_{\mathrm{m}} / d t$. We assume a uniform distribution of bubbles and that all bubbles are carried to the surface within the ascending magma. Consequently, the ascent and growth of bubbles are modeled in a Lagrangian frame of reference (e.g., Proussevitch and Sahagian 2005), with conduit flow formulated in an explicit manner and bubble growth semi-implicitly, similar to Proussevitch et al. (1993).

\section{Magma ascent modeling}

Modeling the Plinian, ultraplinian, and Hawaiian eruptions

For Plinian, ultraplinian, and Hawaiian eruptions, $d P_{\mathrm{m}} / d t$ is calculated using a conduit flow model that assumes onedimensional flow of melt with suspended bubbles that are carried passively with the ascending magma. We model this bubbly flow up to the point where magma fragmentation is predicted by the empirical formulation of Mueller et al. (2008), assuming a characteristic magma permeability of $k \sim 10^{-12} \mathrm{~m}^{2}$. The resultant fragmentation threshold is defined by

$\Delta P=\Delta P_{f}=\frac{2.4}{\phi} \mathrm{MPa}$.

We do not model the flow of magma above the fragmentation depth but instead use the analytical method of Koyaguchi (2005) to estimate exit pressure at the vent, $P_{\text {vent }}$ (Table 5).

For the Hawaiian eruption, there are no feasible solutions that would predict brittle magma fragmentation. This is consistent with the view of hydrodynamical fragmentation during these eruptions (e.g., Namiki and Manga 2008; Houghton and Gonnermann 2008). Accordingly, we model bubbly flow up to the surface (Parfitt 2004), assuming an exit pressure of $10^{5} \mathrm{~Pa}$ at the vent.

We assume isothermal flow with a constant discharge rate, $Q$, in a conduit of constant radius $a$. The rate of change in $P_{\mathrm{m}}$ is calculated in the conventional manner for one-dimensional flow in a cylindrical vertical conduit 
Table 5 Parameters for the model calculations

\begin{tabular}{llllllll}
\hline Parameters & Kilauea & Stromboli & Soufrière Hills & Novarupta & Taupo & Tarawera & Etna \\
\hline Model parameters & & & & & & & \\
$\log \left(N_{\mathrm{m}}\right)\left(\mathrm{m}^{-3}\right)$ & $12-14$ & $12-13$ & $12-16$ & $12-14$ & $12-14$ & $13-14$ & $13-14$ \\
$a(\mathrm{~m})$ & $5-20$ & $2-10$ & 15 & $25-75$ & $25-75$ & $25-50$ & $25-50$ \\
$P_{\text {initial }}(\mathrm{MPa})$ & 4 & 87 & $20-80$ & 53 & 100 & 87 & 41 \\
$\left.d P_{\mathrm{m}} / d t(\mathrm{MPa} \mathrm{s})^{-1}\right)$ & - & - & $1-10$ & - & - & - & - \\
Vent pressure calculation & & & & & & & \\
$P_{\text {initial }}(\mathrm{MPa})$ & 4 & 87 & 80 & 53 & 100 & 87 & 41 \\
$z_{\text {initial }}(\mathrm{km})$ & 0.16 & 3.3 & 3 & 2 & 3.8 & 3.3 & 1.6 \\
$P_{\text {frag }}(\mathrm{MPa})$ & - & - & - & 4 & 1.8 & 28 & 8.4 \\
$\Delta P(\mathrm{MPa})$ & - & - & 2.9 & 3.7 & 3 & 7 & 4.7 \\
Fragmentation depth $(\mathrm{km})$ & - & - & - & 1.2 & 1.5 & 1.7 & 0.5 \\
$P_{\text {vent }}(\mathrm{MPa})$ & - & - & - & 0.95 & 0.53 & 6.2 & 3.7 \\
\hline
\end{tabular}

(e.g., Wilson 1980; Dobran 1992; Mastin 2002; Proussevitch and Sahagian 2005)

$\frac{d P_{\mathrm{m}}}{d t}=-\rho g u-f_{\mathrm{m}} \frac{\rho u^{3}}{4 a}$.

Here, $g$ is the acceleration due to gravity and $u=d z / d t=$ $Q /\left(\pi a^{2} \rho\right)$ is the magma ascent velocity, with $z$ denoting the vertical coordinate. $\rho=\rho_{\mathrm{m}}(1-\phi)$ is magma density, $\rho_{\mathrm{m}}$ is the melt density, which is assumed to be constant, and $\phi=R^{3} / S^{3}$ is the volume fraction of vesicles, where $S$ is the half distance between two bubbles. $f_{\mathrm{m}}=64 / \mathrm{Re}+f_{0}$ is the friction factor for pipe flow, with $f_{0}=0.02$ and Reynolds number, $\operatorname{Re}=\rho u a / \eta$ (e.g., Wilson 1980). We find that values of $f_{0}$ corresponding to wall roughnesses of approximately $0.1-1 \%$ of the conduit diameter do not significantly affect the results, especially given uncertainties in $a$ and $Q$. For a given $Q, a$ and initial $\mathrm{H}_{2} \mathrm{O}$ (Tables 2, 3, and 5), we solve Eqs. 4, 6, 7, and 9 to estimate $\mathrm{Ca}$ for these eruptions.

\section{Modeling the Strombolian eruption}

For the Strombolian sample, we assume that the sample represents a parcel of magma that was passively carried to the surface by an ascending gas slug or agglomeration of large gas bubbles, consistent with the conceptual model of Lautze and Houghton $(2005,2007)$. The resultant value of $d P_{\mathrm{m}} / d t$ is based on the rate of change in magma-static pressure for ascent velocities of Strombolian gas slugs (Seyfried and Freundt 2000)

$u_{\text {str }}=0.345 \sqrt{2 a g}$.

Neglecting frictional pressure losses, we use

$\frac{d P_{\mathrm{m}}}{d t}=-\rho g u_{\mathrm{str}}$ with a conduit radius of $4 \mathrm{~m}$, a likely lower bound (Pistolesi et al. 2011). We explored conduit radii between 2 and $10 \mathrm{~m}$ (Parfitt 2004; Pistolesi et al. 2011) and found that it does not change the overall model results. Given $u_{\text {str }}$, we solve the coupled Eqs. 4, 6, 7, and 11 to estimate Ca.

Modeling the Vulcanian eruption

Soufrière Hills volcano experienced 88 Vulcanian explosions in 1997, each of which discharged approximately $3 \times 10^{5} \mathrm{~m}^{3}$ of magma (dry rock equivalent), about one-third forming fallout and two-third forming pyroclastic flows (Druitt et al. 2002). Each explosion started by the rupture of a plug of dense and degassed magma (Druitt et al. 2002; Spieler et al. 2004; Burgisser et al. 2010; Burgisser et al. 2011). Triggered decompression caused the fragmentation and eruption of the conduit contents down to a maximum depth of about 2.5-3.5 km (Burgisser et al. 2011) within a time increment of about 10-100 s (Druitt et al. 2002; Melnik and Sparks 2002). Based on matrix-glass water contents of a representative suite of pyroclasts, and taking into account the pre-, syn-, and post-explosive vesiculation processes of a typical 1997 Vulcanian explosion of Soufrière Hills volcano (Giachetti et al. 2010), Burgisser et al. (2010) determined that the pre-explosive pressure of the deepest magma ejected during an explosion is approximately $80 \mathrm{MPa}$, leading to an average decompression rate of about $1-10 \mathrm{MPa} \mathrm{s}^{-1}$, consistent with estimates by Giachetti et al. (2010). Given $d P_{\mathrm{m}} / d t$, as well as initial $\mathrm{H}_{2} \mathrm{O}$ content, we solve Eqs. 4, 6, and 7 to estimate $\mathrm{Ca}$.

Modeling the basaltic Plinian eruptions

Pyroclasts from both basaltic Plinian eruptions (Etna, 122 BC and Tarawera, 1886) contain approximately 60-90\% plagioclase microlites within the groundmass that surrounds the vesicles (Sable et al. 2006, 2009). We account 
for the effect of microlites on magma viscosity using the formulation of Costa et al. (2009), parameterized to fit the viscosities of silicate melts containing plagioclase crystals of similar shape, size, and volume fractions as in the Etna and Tarawera samples (Picard et al. 2011). As shown in Fig. $4 \mathrm{a}$, the relative viscosity, $\eta_{\mathrm{r}}$, which is the viscosity of the crystal-bearing melt divided by the crystal-free melt viscosity, increases rapidly with the volume fraction of plagioclase microlites, $\phi_{x}$, for values of $\phi_{x}>0.3$ (Picard et al. 2011).

It is uncertain at precisely what depth and over what time interval the microlites formed during either eruptions. Although Sable et al. (2006, 2009) inferred that the microlites found in both Etna and Tarawera samples formed syn-eruptively, as a consequence of undercooling
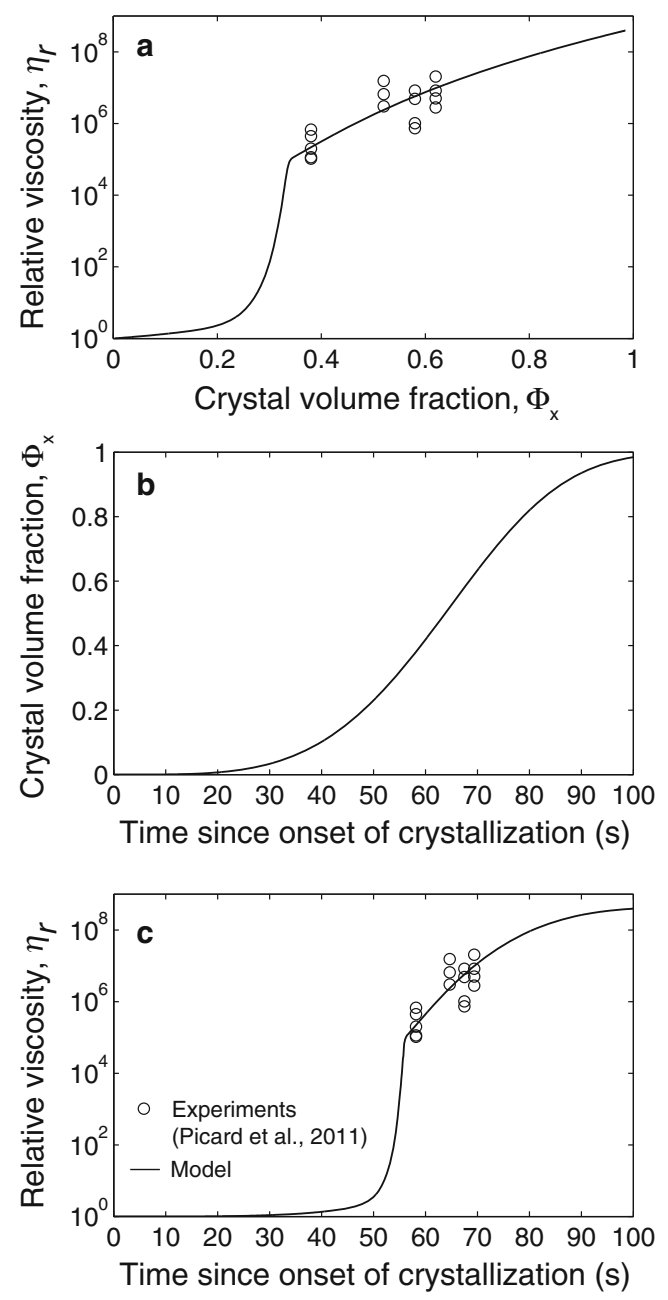

Fig. 4 a Relative viscosity, $\eta_{\mathrm{r}}$, as a function of crystal volume fraction, $\phi_{x}$. The values of $\eta_{\mathrm{r}}$ are calculated using equations $\eta_{\mathrm{r}}=\left(1+\phi^{\delta}\right) /(1-$ $F)^{B \phi_{*}}$ and $F=(1-\xi) \operatorname{erf}\left(\left(\sqrt{\pi} \phi\left(1+\phi^{\gamma}\right)\right) /(2(1-\xi))\right)$ of Costa et al. (2009) with fitting parameters $\delta=8, \gamma=6, B=2.5$, and $\phi_{*}=$ 0.29. b Modeled crystal volume fraction, $\phi_{x}$ (Eq. 12), as a function of time for $I G^{3}=10^{-8} \mathrm{~s}^{-4}$ and $k_{\mathrm{v}}=4 \pi / 3$. c Corresponding relative viscosity, $\eta_{\mathrm{r}}$, as a function of time. The measured values of $\eta_{\mathrm{r}}$ for silicic melt with plagioclase microcrystals (Picard et al. 2011) are shown as open circles at model times corresponding to the values of $\phi_{x}$ in $\mathbf{b}$ during $\mathrm{H}_{2} \mathrm{O}$ exsolution (Hammer 2008), post-eruptive overprinting can obscure syn-eruptive crystallization (Szramek et al. 2006, 2010; Szramek 2010). Furthermore, some microlite crystallization may have occurred during a short time interval prior to eruption (Szramek 2010). We therefore explored a wide range of crystallization rates in our modeling of both eruptions, using the Avrami equation (e.g., Cashman 1993; Marsh 1998; Pupier 2008, and references therein)

$\phi_{x}=1-\exp \left(-k_{\mathrm{v}} I G^{3} t^{4}\right)$.

Here, $I$ is the crystal nucleation rate, $G$ is the crystal growth rate, $t$ is the time from the onset of crystallization, and $k_{\mathrm{V}}$ is a shape factor, for simplicity assumed to be $k_{\mathrm{v}}=4 \pi / 3$ (Marsh 1998). We explored a wide range of values, with $10^{-9} \mathrm{~s}^{-4} \leq\left(I G^{3}\right) \leq 10^{-3} \mathrm{~s}^{-4}$. If crystallization was too early, model simulations predicted magma fragmentation at values of $\phi$ that are significantly smaller than those found in the basaltic Plinian clasts. If crystallization was too late, no magma fragmentation was predicted. However, for a range of crystallization rates $\left(7.5 \leq\left(I G^{3}\right) \leq 8.5 \mathrm{~s}^{-4}\right)$, model results predict magma fragmentation, together with values of $\phi$ and $R$ that are consistent with those measured in the basaltic Plinian samples. These values of $\left(I G^{3}\right)$ are also well within the range of results from plagioclase crystallization experiments (Burkhard 2005; Hammer 2008; Brugger and Hammer 2010). The resultant change in $\phi_{x}$ and $\eta_{\mathrm{r}}$, with respect to time after the onset of crystallization, is shown in Fig. 4b, c for a representative case.

\section{Results and discussion}

Figure 2 indicates that vesicles in pyroclasts from Strombolian and Hawaiian eruptions have distinctly larger values of $\Omega$ than the other eruptions. Vesicle shapes formed during ascent within the conduit may be modified after fragmentation by bubble growth (e.g., Thomas and Sparks 1992; Kaminsky and Jaupart 1997) and shape relaxation due to capillary forces (e.g., Klug and Cashman 1996). However, for silicic and for microlite-rich basaltic magmas, post-fragmentation bubble growth should be of limited extent, due to permeable outgassing (e.g., Rust and Cashmann 2011; Gonnermann and Houghton 2012). Moreover, the characteristic time scale for shape relaxation,

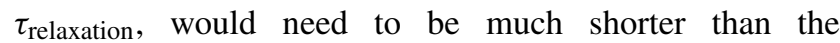
characteristic quenching time, $\tau_{\text {quenching. To evaluate the }}$ effect of post-fragmentation shape relaxation, we estimate $\tau_{\text {quenching }} \sim 100 \mathrm{~s}$ for centimeter-size pyroclasts following the approach of Thomas and Sparks (1992). For Vulcanian, Plinian, ultraplinian, and basaltic Plinian eruptions, $\tau_{\text {relaxation }}=\eta R / \sigma \sim 10^{3}$ to $10^{5} \mathrm{~s} \gg \tau_{\text {quenching }}$ (assuming that the viscosity in the case of the basaltic 
Plinian magmas accounts for the effect of microlites). Consequently, post-fragmentation shape relaxation should be negligible. For the less viscous Hawaiian and Strombolian basalt magmas, $\tau_{\text {relaxation }} \sim 10^{-2}$ to $10^{-3} \mathrm{~s} \ll \tau_{\text {quenching }}$ and bubbles are likely to undergo post-fragmentation shape relaxation. Therefore, the measured values of $\Omega$ for the Hawaiian and Strombolian samples cannot irrevocably be attributed to bubble shapes during magma ascent within the conduit.

Although vesicular volcanic rocks that have undergone vesicle collapse due to open-system degassing can also exhibit complex vesicle shapes (e.g., Adams et al. 2006; Wright et al. 2009), none of the samples analyzed herein have undergone noticeable vesicle collapse nor vesicle elongation due to shear. Volcanic rocks that have undergone vesicle collapse, such as volcanic dome samples, may qualitatively exhibit a range of vesicle shapes, including large elongation and complexly shaped vesicle margins (e.g., Wright and Weinberg 2009). Textures of such samples, if they have small values of $\Omega$, should in principle also be indicative of large capillary numbers, either associated with processes that are not a consequence of decompressiondriven bubble growth (e.g., due to large strain rates associated with bubble collapse at high viscosities) or perhaps as a consequence of preserving some textural remnants of bubble growth (e.g., small strain rates at high viscosity). Consequently, the relationship between $\Omega$, capillary number, $\Delta P$, and fragmentation suggested herein only holds for pyroclastic samples associated with explosive eruptions that have not undergone bubble collapse. For these cases, we therefore suggest that $\Omega$ can be related to $\mathrm{Ca}$, through modeling of the expansion velocity, $v_{\mathrm{e}}$ (Koerner 2008).

Figure 5 shows a representative model result for each eruption as a graph of bubble radius, $R$, overpressure, $\Delta P$, and capillary number as a function of dimensionless pressure, defined as $\hat{P}=\left(P_{\mathrm{m}}-P_{\text {frag }}\right) /\left(P_{\text {initial }}-P_{\text {frag }}\right)$. Note that in the case of Stromboli and Kilauea Iki, the fragmentation threshold is not reached and $P_{\text {frag }}$ is assumed as the vent pressure of $10^{5} \mathrm{~Pa}$. We chose dimensionless $\hat{P}$ as the ordinate, as opposed to dimensional $P_{\mathrm{m}}$ or depth, because $\hat{P}$ facilitates an easier comparison between the individual eruptions. We refer the reader to Table 5 for the different values of $P_{\text {initial }}, P_{\text {frag }}, z_{\text {initial }}$, and fragmentation depth. Although we find from a parametric analysis that the details of the plotted curves will change somewhat within the range of realistic parameter values (Table 2), neither their characteristic shape nor the predicted values of capillary number and $\Delta P$ will be significantly affected.

As magma ascends toward the surface, $P_{\mathrm{m}}$ decreases and water diffuses into growing bubbles. Because the viscosity of silicic magmas depends strongly on the concentration of dissolved $\mathrm{H}_{2} \mathrm{O}$, the increasing viscosity will retard bubble growth and allow the buildup of bubble overpressure, $\Delta P$.
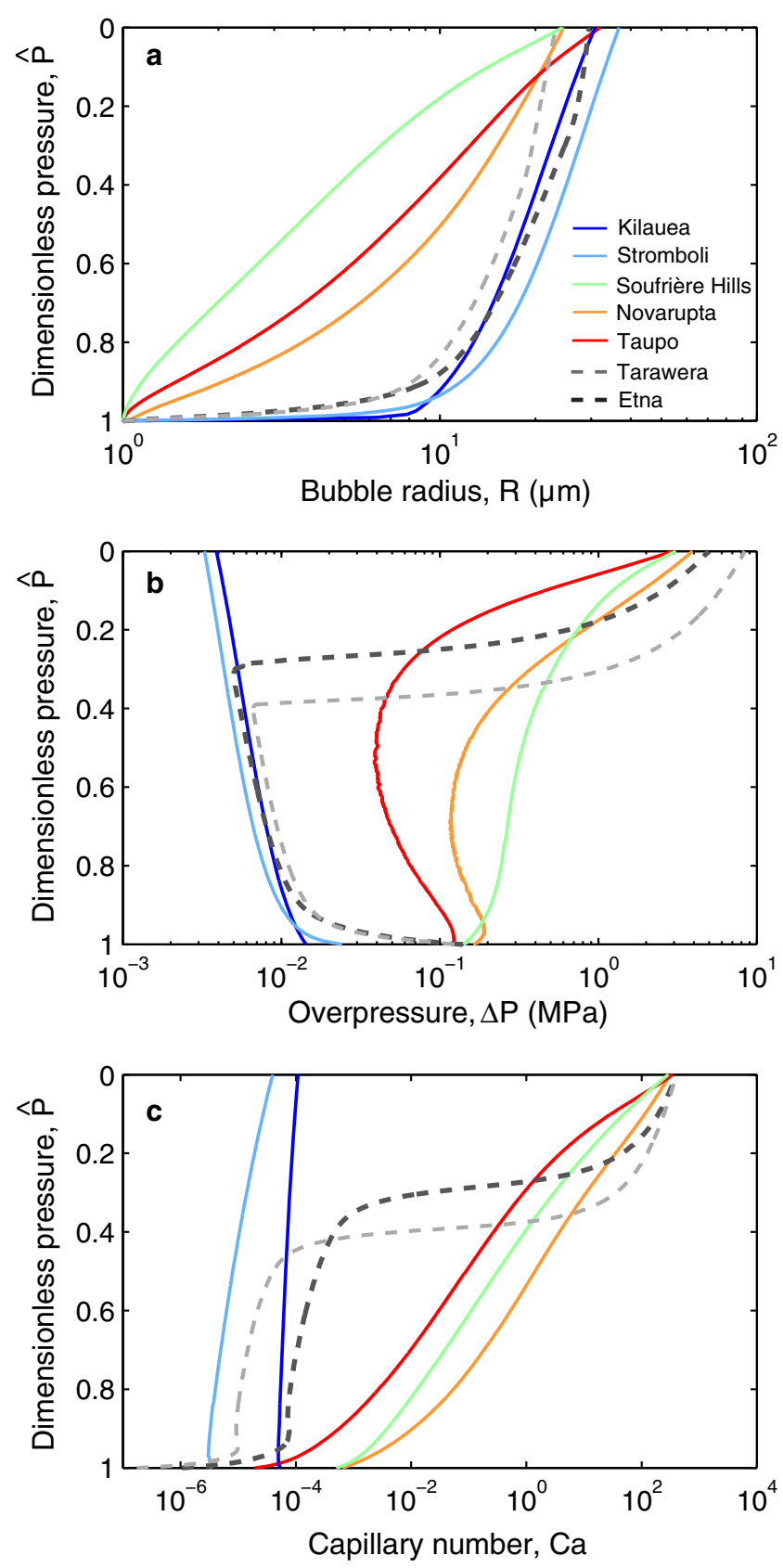

Fig. 5 Plots of dimensionless pressure as a function of a bubble radius, $R$, b overpressure, $\Delta P$, and $\mathbf{c}$ capillary number, Ca. Dimensionless pressure, $\hat{P}$ is defined as $\left(P_{\mathrm{m}}-P_{\text {frag }}\right) /\left(P_{\text {initial }}-P_{\text {frag }}\right)$ (Table 5) for Vulcanian, Plinian, basaltic Plinian, and ultraplinian eruptions, whereas $\hat{P}=P_{\mathrm{m}} / P_{\text {initial }}$ in the case of Stromboli and Kilauea Iki eruptions. Modeled final bubble radii are $20-40 \mu \mathrm{m}$, consistent with vesicle shape quantification. Values of modeled final capillary number obtained for Hawaiian and Strombolian eruptions are smaller than those obtained for Vulcanian, Plinian, and ultraplinian eruptions

At the same time, the capillary number will increase to values $\gg 1$. Although the viscosity of basaltic melt is much less affected by $\mathrm{H}_{2} \mathrm{O}$ exsolution, the resultant undercooling may induce significant crystallization, as suggested for Etna and Tarawera basaltic Plinian eruptions (Sable et al. 2006, 
2009). The microlites found in Etna and Tarawera samples must have produced a significant increase in viscosity (see Fig. 4a; Picard et al. 2011); however, the timing of microlite formation is somewhat uncertain (Szramek et al. 2006, 2010; Goepfert and Gardner 2010; Szramek 2010).

Here, we show through combined bubble growth and conduit flow modeling that the basaltic Plinian eruptions of Etna and Tarawera can be explained by syn-eruptive crystallization, buildup of overpressure, and brittle fragmentation. Both, pre- and syn-eruptive crystallization are consistent with vesicle shapes $(\Omega<1$ and $\mathrm{Ca} \gg 1)$. However, conduit flow modeling indicates that the viscosity of the microlite-rich magma would require magma fragmentation within a short distance of the pre-eruptive reservoir, as the large magma viscosity would otherwise inhibit magma ascent to the surface. Regardless, the model results demonstrate that the increase in viscosity due to microlites will result in $\mathrm{Ca} \gg 1$ for these eruptions, consistent with $\Omega<1$. Therefore, our results support the hypothesis that basaltic
Plinian eruptions were, like their silicic counterparts, associated with overpressure and brittle magma fragmentation as a consequence of high viscosity (Sable et al. 2006, 2009; Houghton and Gonnermann 2008).

The relationships of $\Omega$ and predicted capillary number for the different eruptions are shown in Fig. 6. All the silicic eruptions, which presumably were associated with brittle fragmentation, have larger values of $(1-\Omega)$ (i.e., smaller values of $\Omega$ ) than the Strombolian and Hawaiian style eruptions, as well as $\mathrm{Ca} \gg 1$. This is also the case for the basaltic Plinian eruptions. In contrast, for the Hawaiian and Strombolian eruptions, our model results indicate that $\mathrm{Ca} \ll 1$, with insufficient overpressure for brittle fragmentation, thus consistent with the work of Namiki and Manga (2008). Although our model results imply that bubble shapes for the Hawaiian and Strombolian eruptions should have had values of $\Omega \approx 1$ during magma ascent within the conduit, this cannot be established unequivocally because of post-fragmentation shape relaxation.

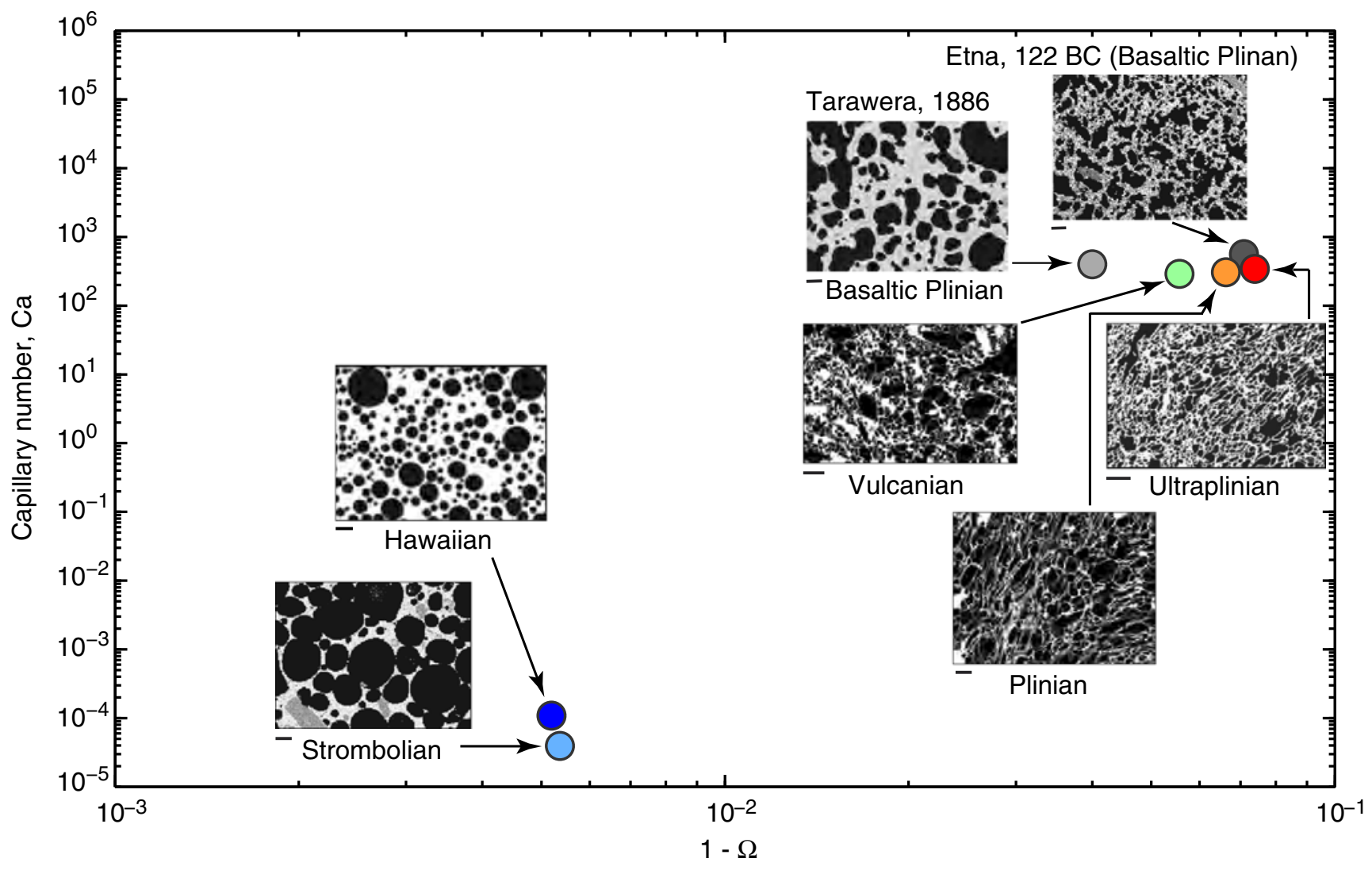

Fig. 6 Measured median $(1-\Omega)$ versus calculated capillary number, $\mathrm{Ca}$, for the clasts analyzed herein (Table 4), with images thereof shown as insets (the scale bar at the bottom left of each image is $100 \mu \mathrm{m}$ in length). Capillary numbers represent the values at magma fragmentation for Vulcanian, Plinian and ultraplinian eruptions, or at $P_{\mathrm{m}}=10^{5} \mathrm{~Pa}$ for Hawaiian and Strombolian eruptions. A clear dis- tinction exists between Hawaiian and Strombolian eruptions (smaller $(1-\Omega)$ and $\mathrm{Ca} \ll 1)$, and the other eruptions (larger $(1-\Omega)$ and $\mathrm{Ca} \gg 1)$. This distinct dichotomy in $\Omega$ and $\mathrm{Ca}$ is mirrored in inferred fragmentation style, with brittle fragmentation of magma occurring in Vulcanian, Plinian, basaltic Plinian, and ultraplinian eruptions 


\section{Conclusions}

Vesicle shapes in pyroclasts from fall deposits of a wide range of explosive volcanic eruptions were quantified using the shape parameter $\Omega$. When compared to estimates of capillary number, based on the expansion velocity obtained from bubble growth modeling, we find a clear distinction of Hawaiian and Strombolian eruptions $(\Omega \approx 1, \mathrm{Ca} \ll 1)$ versus eruptions of higher intensity $(\Omega<1, \mathrm{Ca} \gg 1)$, such as Vulcanian, Plinian, and ultraplinian. Importantly, basaltic Plinian eruptions are distinctly different in $\Omega$ and in capillary number from Strombolian and Hawaiian eruptions. This suggests that the presence of abundant plagioclase microlites resulted in a sufficient increase in viscosity to result in overpressure for brittle fragmentation during the basaltic Plinian eruptions, akin to their silicic counterparts, which do not contain large abundances of microlites.

Acknowledgments The study was funded by the National Science Foundation grants EAR-1019872 and EAR-0810332. The authors thank J. E. Gardner, A. A. Proussevitch, and one anonymous reviewer for the thorough and constructive comments.

\section{References}

Adams NK, Houghton BF, Hildreth W (2006) Abrupt transitions during sustained explosive eruptions: examples from the 1912 eruption of Novarupta, Alaska. Bull Volcanol 69:189-206

Amon M, Denson CD (1984) A study of the dynamics of foam growth: analysis of the growth of closely spaced spherical bubbles. Poly Eng Sci 24:1026-1034

Arefmanesh A, Advani SG (1991) Diffusion-induced growth of a gas bubble in a viscoelastic fluid. Rheol Acta 30:274-283

Alidibirov M (1994) A model for viscous magma fragmentation during volcanic blasts. Bull Volcanol 56:459-465

Blackburn EA, Wilson L, Sparks RSJ (1976) Mechanisms and dynamics of strombolian activity. J Geol Soc Lon 132:429-440

Brugger CR, Hammer JE (2010) Crystallization kinetics in continuous decompression experiments: implications for interpreting natural magma ascent processes. J Petrol 51:1941-1965

Burkhard DJM (2005) Nucleation and growth rates of pyroxene, plagioclase, and Fe-Ti oxides in basalt under atmospheric conditions. Eur J Mineral 17:675-685

Burgisser A, Gardner JE (2005) Experimental constraints on degassing and permeability in volcanic conduit flow. Bull Volcanol 67:42-56

Burgisser A, Poussineau S, Arbaret L, Druitt TH, Giachetti T, Bourdier J-L (2010) Pre-explosive conduit conditions of the 1997 Vulcanian explosions at Soufrière Hills Volcano (Montserrat): I. Pressure and vesicularity distributions. J Volcanol Geotherm Res 194:27-41

Burgisser A, Arbaret L, Druitt TH, Giachetti T (2011) Pre-explosive conduit conditions of the 1997 Vulcanian explosions at Soufrière Hills Volcano (Montserrat): II. Overpressure and depth distributions. J Volcanol Geotherm Res 199:193-205

Burton M, Allard P, Murè F, La Spina A (2007) Magmatic gas composition reveals the source depth of slug-driven Strombolian explosive activity. Science 317:227-230

Cashman KV (1993) Relationship between plagioclase crystallization and cooling rate in basaltic melts. Conrib Mineral Petrol 113: $126-142$
Cashman KV, Mangan MT (1994) Physical aspects of magmatic degassing: II. Constraints on vesiculation processes from textural studies of eruptive products. In: Carroll MR, Holloway JR (eds) Volatiles in magmas. Reviews in mineralogy, vol 30. Minarological Society of America, Washington, DC, pp 447-478

Coltelli M, Del Carlo P, Vezzoli L (1998) Discovery of a Plinian basaltic eruption of Roman age at Etna volcano, Italy. Geology 26:1095-1098

Costa A, Caricchi L, Bagdassarov N (2009) A model for the rheology of particle-bearing suspensions and partially molten rocks. Geochem Geophys Geosys 10(3):Q03010. doi:10.1029/ 2008GC002138

Costantini L, Bonadonna C, Houghton B, Wehrmann H (2009) New physical characterization of the Fontana lapilli basaltic Plinian eruption, Nicaragua. Bull Volcanol 71:337-355

Del Carlo P, Pompilio M (2004) The relationship between volatile content and the eruptive style of basaltic magma: the Etna case. Annal Geophys 47:1423-1432

Dingwell DB (1996) Volcanic dilemma: flow or blow? Science 273:1054-1055

Dixon JE (1997) Degassing of alkalic basalts. Am Mineral 82:368-378

Dobran F (1992) Nonequilibrium flow in volcanic conduits and applications to the eruptions of Mount St. Helens on May 18, 1980, and Vesuvius in A.D. 79. J Volcanol Geotherm Res 49:285-311

Druitt TH, Young SR, Baptie B, Bonadonna C, Calder ES, Clarke AB, Cole PD, Harford CL, Herd RA, Luckett R, Ryan G, Voight B (2002) Episodes of cyclic Vulcanian explosive activity with fountain collapse at Soufrière Hills Volcano, Montserrat. In: Druitt TH, Kokelaar BP (eds) The eruption of the Soufrière Hills Volcano from 1995 to 1999, Montserrat, Antilles. Geol Soc London Mem, vol 21, pp 281-306

Dunbar N, Kyle PR, Wilson CJN (1989) Evidence of limited zonation in silicic magma systems, Taupo Volcanic Zone, New Zealand. Geology 17:234-236

Dunbar NW, Kyle P (1993) Lack of volatile gradient in the Taupo plinian-ignimbrite transition: evidence from melt inclusion analysis. Am Mineral 78:612-618

Gamble JA, Smith IEM, Graham IJ, Kokelaar BP, Cole JW, Houghton BF, Wilson CJN (1990) The petrology, phase relations and tectonic setting of basalts from the Taupo Volcanic Zone, New Zealand and the Kermadec Island Arc-Havre Trough, SW Pacific. J Volcanol Geotherm Res 43:235-270

Gardner JE (2007) Bubble coalescence in rhyolitic melts during decompression from high pressure. J Volcanol Geotherm Res 166:161-176

Gardner JE, Ketcham RA (2011) Bubble nucleation in rhyolite and dacite melts: temperature dependence of surface tension. Contrib Mineral Petr 162:929-943

Giachetti T, Druitt TH, Burgisser A, Arbaret L, Galven C (2010) Bubble nucleation, growth and coalescence during the 1997 Vulcanian explosions of Soufrière Hills Volcano, Montserrat. J Volcanol Geotherm Res 193:215-231

Giordano D, Dingwell DB (2003) Viscosity of hydrous Etna basalt: implications for Plinian-style basaltic eruptions. Bull Volcanol 65:8-14

Goepfert K, Gardner JE (2010) Influence of pre-eruptive storage conditions and volatile contents on explosive Plinian style eruptions of basic magma. Bull Volcanol 72:511-521

Gonnermann HM, Manga M (2007) The fluid mechanics inside a volcano. Annu Rev Fluid Mech 39:321-356

Gonnermann HM, Houghton BF (2012) Magma degassing during the Plinian eruption of Novarupta, Alaska, 1912. Geochem Geophys Geosys 13:Q10009. doi:10.1029/2012GC00427

Hammer J, Rutherford M, Hildreth W (2002) Magma storage prior to the 1912 eruption at Novarupta, Alaska. Contrib Mineral Petr 144:144-162 
Hammer J (2008) Experimental studies of the kinetics and energetics of magma crystallization. Rev Mineral Petr 69:9-59

Hildreth W, Fierstein J (2012) The Novarupta-Katmai eruption of 1912 Largest eruption of the twentieth century: centennial perspectives. US Geol Surv Prof Pap 1791:259

Houghton BF, Wilson CJN, Carlo PD, Coltelli M, Sable JE, Carey R (2004) The influence of conduit processes on changes in style of basaltic plinian eruptions: Tarawera 1886 and Etna 122 BC. J Volcanol Geotherm Res 137:1-14

Houghton BF, Gonnermann HM (2008) Basaltic explosive volcanism: constraints from deposits and models. Chem Erde 68:117-140

Houghton BF, Carey RJ, Cashman KV, Wilson CJN, Hobden BJ, Hammer JE (2010) Diverse patterns of ascent, degassing, and eruption of rhyolite magma during the 1.8 ka Taupo eruption, New Zealand: evidence from clast vesicularity. J Volcanol Geotherm Res 195:31-47

Hui H, Zhang Y (2007) Toward a general viscosity equation for natural anhydrous and hydrous silicate melts. Geochim Cosmochim Acta 71:403-416

Kaminski E, Jaupart C (1997) Expansion and quenching of vesicular magma fragments in Plinian eruptions. J Geophys Res 102: 11287-12203

Kerrick D, Jacobs G (1981) A modified Redlich-Kwong equation for $\mathrm{H}_{2} \mathrm{O}, \mathrm{CO}_{2}$, and $\mathrm{H}_{2} \mathrm{O}-\mathrm{CO}_{2}$ mixtures at elevated pressures and temperatures. Am J Sci 281:735-767

Klug C, Cashman KV (1996) Permeability development in vesiculating magmas: implications for fragmentation. Bull Volcanol 58:87100

Koerner C (2008) Foam formation mechanisms in particle suspensions applied to metal foams. Mater Sci Eng A 495:227-235

Koyaguchi T (2005) An analytical study for 1-dimensional steady flow in volcanic conduits. J Volcanol Geotherm Res 143:29-52

Lautze NC, Houghton B (2005) Physical mingling of magma and complex eruption dynamics in the shallow conduit at Stromboli volcano, Italy. Geology 33:425-428

Lautze NC, Houghton BF (2007) Linking variable explosion style and magma textures during 2002 at Stromboli volcano, Italy. Bull Volcanol 69:445-460

Lensky NG, Lyakhovsky V, Navon O (2001) Radial variations of melt viscosity around growing bubbles and gas overpressure in vesiculating magmas. Earth Planet Sci Lett 186:1-6

Liu Y, Zhang Y, Behrens $\mathrm{H}$ (2005) Solubility of $\mathrm{H}_{2} \mathrm{O}$ in rhyolitic melts at low pressures and a new empirical model for mixed $\mathrm{H}_{2} \mathrm{O}-\mathrm{CO}_{2}$ solubility in rhyolitic melts. J Volcanol Geotherm Res 143:219235

Mangan MT, Cashman KV, Newman S (1993) Vesiculation of basaltic magma during eruption. Geology 21:157-160

Mangan MT, Cashman KV (1996) The structure of basaltic scoriaand reticulite and inferences for vesiculation, foam formation, and fragmentation in lava fountains. J Volcanol Geotherm Res 73:1-18

Marsh BD (1998) On the interpretation of crystal size distributions in magmatic systems. J Petrol 39:553-599

Mastin LG (2002) Insights into volcanic conduit flow from an open-source numerical model. Geochem Geophy Geosy 3:1037. doi:10.1029/2001GC000192

McBirney A, Murase T (1970) Factors governing the formation of pyroclastic rocks. Bull Volcanol 34:372-384

Melnik O, Sparks RSJ (2002) Modelling of conduit flow dynamics during explosive activity at Soufrière Hills Volcano, Montserrat. In: Druitt TH, Kokelaar BP (eds) The eruption of Soufrière Hills Volcano, Montserrat, from 1995 to 1999. Geological Society, London, Memoirs, vol 21, pp 307-317

Mueller S, Scheu B, Spieler O, Dingwell DB (2008) Permeability control on magma fragmentation. Geology 36:399-402
Namiki A, Manga M (2006) Influence of decompression rate on the expansion velocity and expansion style of bubbly fluids. J Geophys Res 111:B11208. doi:10.1029/2005JB004132

Namiki A, Manga M (2008) Transition between fragmentation and permeable outgassing of low viscosity magmas. J Volcanol Geotherm Res 169:48-60

Okumura S, Nakamura M, Tsuchiyama A, Nakano T, Uesugi K (2008) Evolution of bubble microstructure in sheared rhyolite: formation of a channel-like bubble network. J Geophys Res 133:B07208. doi:10.1029/2007JB005362

Parfitt EA (2004) A discussion of the mechanisms of explosive basaltic eruptions. J Volcanol Geotherm Res 134:77-107

Picard D, Arbaret L, Pichavant M, Champallier R, Launeau P (2011) Rheology and microstructure of experimentally deformed plagioclase suspensions. Geology 39:747-750

Pistolesi M, Delle Donne D, Pioli L, Rosi M, Ripepe M (2011) The 15 March 2007 explosive crisis at Stromboli volcano, Italy: assessing physical parameters through a multidisciplinary approach. J Geophys Res 116:B12206. doi:10.1029/2011JB008527

Polacci M, Pioli L, Rosi M (2003) The Plinian phase of the Campanian Ignimbrite eruption (Phlegrean Fields, Italy): evidence from density measurements and textural characterization of pumice. Bull Volcanol 65:418-432

Proussevitch AA, Sahagian DL, Anderson AT (1993) Dynamics of diffusive bubble growth in magmas: isothermal case. J Geophys Res 98:22283-22307

Proussevitch A, Sahagian D (2005) Bubbledrive-1: a numerical model of volcanic eruption mechanisms driven by disequilibrium magma degassing. J Volcanol Geotherm Res 143:89-111

Proussevitch AA, Sahagian DL, Tsentalovich EP (2007) Statistical analysis of bubble and crystal size distributions: formulations and procedures. J Volcanol Geotherm Res 164:95-111

Pupier E, Cuchene S, Toplis MJ (2008) Experimental quantification of plagioclase crystal size distribution during cooling of a basaltic liquid. Contrib Mineral Petrol 155:555-570

Rallison JM (1984) The deformation of small viscous drops and bubbles in shear flows. Annu Rev Fluid Mech 16:45-66

Ripepe M, Ciliberto S, Della Schiava M (2001) Time constraints for modeling source dynamics of volcanic explosions at Stromboli. J Geophys Res 106:8713-8727

Russ JC, Dehoff RT (2000) Practical Stereology, 2nd Ed. Kluwer, New York, $\mathrm{p} 382$

Rust AC, Manga M (2002a) Bubble shapes and orientations in low Re simple shear flow. J Colloid Interface Sci 249:476-480

Rust AC, Manga M (2002b) Effects of bubble deformation on the viscosity of dilute suspensions. J NonNewt Fluid Mech 104:53-63

Rust AC, Manga M, Cashman KV (2003) Determining flow type, shear rate and shear stress in magmas from bubble shapes and orientations. J Volcanol Geotherm Res 122:111-132

Rust AC, Cashman KV (2011) Permeability controls on expansion and size distributions of pyroclasts. J Geophys Res 116:B11202

Sable JE, Houghton BF, Del Carlo P, Coltelli M (2006) Changing conditions of magma ascent and fragmentation during the Etna 122 $\mathrm{BC}$ basaltic Plinian eruption: evidence from clast microtextures. J Volcanol Geotherm Res 158:333-354

Sable JE, Houghton BF, Wilson CJN, Carey RJ (2009) Eruption mechanisms during the climax of the Tarawera 1886 basaltic Plinian eruption inferred from microtextural characteristics of the deposits. In: Thordarson T, Self S, Larsen J, Rowland K, Hoskuldsson A (eds) Studies in volcanology. The legacy of George Walker. Geological Society, London, pp 129-154

Schneider CA, Rasband WS, Eliceiri KW (2012) NIH Image to ImageJ: 25 years of image analysis. Nat Methods 9:671-675

Scriven L (1959) On the dynamics of phase growth. Chem Eng Sci 10:1-13 
Seyfried R, Freundt A (2000) Experiments on conduit flow and eruption behavior of basaltic volcanic eruptions. J Geophys Res 105:23727-23740

Shea T, Houghton BF, Gurioli L, Cashman KV, Hammer JE, Hobden BJ (2010) Textural studies of vesicles in volcanic rocks: an integrated methodology. J Volcanol Geotherm Res 190:271-289

Sparks RSJ (1978) The dynamics of bubble formation and growth in magmas: a review and analysis. J Volcanol Geotherm Res 3:1-37

Spieler O, Kennedy B, Kueppers U, Dingwell DB, Scheu B, Taddeucci J (2004) The fragmentation threshold of pyroclastic rocks. Earth Planet Sci Lett 226:139-148

Stone HA (1994) Dynamics of drop deformation and breakup in viscous fluids. Annu Rev Fluid Mech 26:65-102

Stovall WK, Houghton BF, Gonnermann HM, Fagents SA, Swanson DA (2011) Eruption dynamics of Hawaiian-style fountains: the case study of episode 1 of the Kilauea Iki 1959 eruption. Bull Volcanol 73:511-529

Szramek L, Gardner JE, Larsen J (2006) Degassing and microlite crystallization of basaltic andesite magma erupting at Arenal volcano, Costa Rica. J Volcanol Geotherm Res 157:182-201

Szramek LA (2010) Basaltic volcanism: deep mantle recycling, Plinian eruptions, and cooling-induced crystallization. $\mathrm{PhD}$ thesis, UT Austin

Szramek L, Gardner JE, Hort M (2010) Cooling-induced crystallization of microlite crystals in two basaltic pumice clasts. Am Mineral 95:503-509

Taylor GI (1932) The viscosity of a fluid containing small drops of another fluid. Proc Roy Soc A 138:41-48

Taylor GI (1934) The formation of emulsions in definable fields of flow. Proc Roy Soc A 146:501-523
Thomas RME, Sparks RSJ (1992) Cooling of tephra during fallout from eruption columns. Bull Volcanol 54:542-553

Vergniolle S, Mangan M (2000) Hawaiian and Strombolian eruptions. In: Sigurdsson H, Houghton BF, McNutt S, Rymer H, Stix J (eds) Encyclopedia of volcanoes. Academic, San Diego, pp 447-461

Walker GPL (1973) Explosive volcanic eruptions-a new classification scheme. Geol Rund 62:431-446

Walker G (1980) The Taupo pumice_-product of the most powerful known (ultraplinian) eruption. J Volcanol Geotherm Res 8:69-94

Walker GPL, Self S, Wilson L (1984) Tarawera 1886, New Zealand-a basaltic Plinian fissure eruption. J Volcanol Geotherm Res 21:6178

Wallace PJ, Anderson ATJr (1998) Effects of eruption and lava drainback on the $\mathrm{H}_{2} \mathrm{O}$ contents of basaltic magmas at Kilauea volcano. Bull Volcanol 59:327-344

Wilson L (1980) Relationships between pressure, volatile content and ejecta velocity in three types of volcanic explosion. J Volcanol Geotherm Res 8:297-313

Wright HM, Cashman KV, Gottesfeld EH, Roberts JJ (2009) Strain localization in vesicular magma: implications for rheology and fragmentation. Geology 37:1023-1026

Wright HM, Weinberg RF (2009) Pore structure of volcanic clasts: measurements of permeability and electrical conductivity. Earth Planet Sci Lett 280:93-104

Zhang YX (1999) A criterion for the fragmentation of bubbly magma based on brittle failure theory. Nature 402:648-650

Zhang Y, Behrens $\mathrm{H}$ (2000) $\mathrm{H}_{2} \mathrm{O}$ diffusion in rhyolitic melts and glasses. Chem Geol 169:243-262

Zhang Y, Xu Z, Zhu M, Wang H (2007) Silicate melt properties and volcanic eruptions. Rev Geophys 45:1-27 